\title{
Larvicidal Activity of the Leaf Extracts and Powder of Millettia aboensis Against Larvae of Anopheles gambiae s. l. Collected from Lafia, Nasarawa State, Nigeria
}

\author{
Pam VA ${ }^{1 *}$, Odey $S A^{1}$, Ombugadu $A^{1}$, Uzoigwe $\mathrm{N} \mathrm{R}^{1}$, Yohanna JA ${ }^{2}$, Maikenti J I ${ }^{1}$, Adejoh V A ${ }^{1}$, Ahmed \\ $\mathrm{H} \mathrm{O}^{1}$, Aimankhu PO ${ }^{1}$, Aliyu A A ${ }^{1}$, Ayuba $\mathrm{S} \mathrm{O}^{1}$, Anyebe G $\mathrm{E}^{1}$ and Ashigar $\mathrm{M} \mathrm{A}^{1}$ \\ ${ }^{1}$ Department of Zoology, Faculty of Science, Federal University of Lafia, Nasarawa State, Nigeria. \\ ${ }^{2}$ Department of Zoology, Faculty of Natural Sciences, University of Jos, Plateau State, Nigeria.
}

*Corresponding author: Pam V A, Department of Zoology, Faculty of Science, Federal University of Lafia, Lafia, Nasarawa State, Nigeria; E-mail: vicpam2004@gmail.com

\section{ARTICLE INFO}

Received: 幽 September 22, 2021

Published: 业 October 04, 2021

Citation: Pam VA, Odey S A, Ombugadu A, Uzoigwe N R, Yohanna JA, et al., Larvicidal Activity of the Leaf Extracts and Powder of Millettia aboensis Against Larvae of Anopheles gambiae s. l. Collected from Lafia, Nasarawa State, Nigeria. Biomed J Sci \& Tech Res 39(2)-2021. BJSTR. MS.ID.006262.

Keywords: Anopheles gambiae larvae; Millettia aboensis; Aqueous Extract; Methanolic Extract; Leaf Powder; Lafia

\begin{abstract}
Mosquito control faces constant setbacks due to their resistance to chemical insecticides. Thus, the need to develop bio-larvicides that targets the larval stages of mosquitoes before their emergence to adults. Hence, the study on larvicidal activity of the leaf extracts and powder of Millettia aboensis against larvae of Anopheles gambiae s. l. was conducted. Fresh leaves of M. aboensis were collected from Tudun Kauri, Lafia, Nasarawa State in which a part of the collection was subjected to extraction by maceration, using methanol and distilled water while the other part was air dried. The extracts and leaf powder were prepared into varying concentrations $(25 \mathrm{mg} / \mathrm{ml}, 50 \mathrm{mg} /$ $\mathrm{ml}, 75 \mathrm{mg} / \mathrm{ml}, 125 \mathrm{mg} / \mathrm{ml}$ and $250 \mathrm{mg} / \mathrm{ml}$ ) for the bioassays. After 72 hours exposure period, the $250 \mathrm{mg} / \mathrm{ml}$ concentration yielded the mortality rate of $100 \%, 95 \%$ and $41 \%$ for aqueous, methanolic and leaf powder treatments respectively which varied significantly $(\mathrm{P}<0.0001)$ between concentrations in each of the treatment. The $\mathrm{LC}_{50}$ value obtained showed that the methanolic leaf extract would be the most effective to use. For the $\mathrm{LC}_{90}$ value recorded, the leaf powder would be most effective at 24 hours, while the methanolic leaf extract would be most effective to kill 90\% of Anopheles gambiae larvae at 48 and 72 hours. In conclusion, the methanolic leaf extract should be explored for bio-larvicidal development since it showed a potent and better larvicidal efficacy.
\end{abstract}

\section{Introduction}

Mosquitoes are an important group of insects of public health importance, which transmit human diseases like filariasis, Dengue, Malaria, Japanese encephalitis and yellow fever, resulting in millions of deaths worldwide every year [1]. Malaria is the most prevalent mosquito-borne disease, globally affecting about 3.5 billion persons per annum and the causative pathogen (Plasmodium) is vectored by the Anopheles mosquito [2,3]. An. gambiae is an effective vector of human malaria and lymphatic filariasis (el ephantiasis). Despite several efforts in controlling this vector, the medical and economic burdens caused by it continue to grow [4]. The failure in current control measures and the growing insecticide resistance is necessitating the search for newer and more effective control strategies [5]. One of the approaches for controlling this mosquito borne disease is to interrupt the disease transmission through mosquito control or avoiding mosquito bite. The primary public health intervention for reducing malaria transmission at 
the community level is through vector control and it is the only intervention that can reduce malaria transmission from very high levels to close to zero [3]. Among the most preferred target for mosquito control is the larval stage, because the larva has low mobility, making treatment to be easily localized in time and space as compared to the adult stage [6]. Many approaches have been developed to prevent mosquito menace and the diseases they spread. One of such strategies has been based on the use of synthetic insecticides to interrupt the disease transmission cycle by either targeting the mosquito larvae at breeding sites (through spraying of stagnant water) or by killing or repelling the adult mosquitoes [7]. Though effective, these have created problems like toxicity to humans and non-target populations, long persistence in environment and entry in the food chain [8]. These problems have necessitated the need to develop environmentally safe, biodegradable, economical and indigenous methods of vector control that can be used with minimum care by individuals and communities [9].

Plant products with potentials to act as insecticides or repellent can play an important role in the interruption of transmission of mosquito borne disease at the individual as well as community level [10]. The secondary metabolites in different plants make up a vast repository of compounds with a wide range of biological activities [11]. Millettia aboensis has been used by traditional medicinal practitioners to manage constipation, respiratory difficulties, colds and headaches [12]. The ethanol extract of the root is also used in the study of anti-inflammatory, antioxidant and antimicrobial activity and also macerated root in alcohol is used to treat hernias and jaundice [13]. This study aims to investigate the larvicidal potential of Millettia aboensis against larval stages of Anopheles gambiae.

\section{Materials And Methods}

\section{Study Area}

This study was conducted in the Federal University of Lafia, Nasarawa state. The City of Lafia, Capital of Nasarawa State has farming as the main occupation of its residents, and it boasts crops such as cassava, yam, rice, maize, guinea corn, beans, soya beans, asha, groundnut, vegetables, sugar cane and millet. Also present in the State are mineral resources like columbite, coal and aquamarine. Residents in this area are prone to mosquito-borne diseases as a result of their farming activities [14].

\section{Plant Sample Collection and Identification}

Millettia aboensis plant leaves were sought for and collected locally from farmlands around the Lafia metropolis, Nasarawa State, Nigeria. The plant collected was identified and authenticated botanically at the Federal College of Forestry, Jos, with Herbarium Number 235

\section{Preparation and Extraction of Plant Sample}

Leaves of M. aboensis were washed and air dried at room temperature, devoid of sunlight. Dried samples were ground into powdered form using mortar and pestle and then sieved to get fine powder, which was seperated into two portions. One portion of the powdered plant material was further divided into two parts and then each part (400g each) extracted with methanol (4 litres) and distilled water (4 litres) by maceration [8]. The extract was filtered and allowed to evaporate to dryness at room temperature $\left(31^{\circ} \mathrm{C}\right)$. The dried extract was then transferred into an air-tight container and preserved in the refrigerator, prior to use.

\section{Qualitative/Quantitative Phytochemical Screening of Millettia Aboensis}

The leaf extracts of M. aboensis was screened for phytochemical constituents at the National Research Institute for Chemical Technology (NARICT), Zaria, utilizing standard methods of analysis [15-18].

\section{Mosquito Larvae Collection and Identification}

Anopheles gambiae larvae were collected from rock pools made as a result of quarrying activity in Arikpa-Randa, Nasarawa Eggon, Nasarawa State, located at latitude $08^{\circ} 41.408^{\prime} \mathrm{N}$ and longitude $008^{\circ} 20.835^{\prime} \mathrm{E}$. The collected larvae were colonized in the laboratory in Department of Zoology, Federal University of Lafia prior to larvicidal test, and species identified using taxonomic key by [10]. The larvae were fed by adding finely ground powdered yeast on the surface of the water.

\section{Larvicidal Test}

Bioassay was carried out according to the WHO standard procedures for laboratory testing of mosquito larvicides [19]. The methanol leaf extract of $M$. aboensis were evaluated using different concentrations of $25,50,75,125$ and $250 \mathrm{mg} / \mathrm{ml}$. Distilled water only $(100 \mathrm{ml})$ was used as negative control, while distilled water (100 ml) to which $1 \mathrm{ml}$ methanol was added was used as positive control. Twenty larvae of each mosquito species were put into each of seven disposable $250 \mathrm{ml}$ bowls (controls inclusive) containing $100 \mathrm{ml}$ of distilled water, to which a measured concentration of the test solution was added. Larval mortality was counted at 24, 48 and 72 hours after treatment. Mortality was calculated at each time interval, replicated four times and the results used to determine the $\mathrm{LC}_{50}$ and $\mathrm{LC}_{90}$ values for the extract by Probit analysis. Larvae were considered either alive, if they were clearly moving normally, or dead when there is no movement and no response to gentle probing on the abdomen with a needle. The interpretation of the mortality rate of Anopheles larvae based on WHO [19] susceptibility tests was: 
a) Mortality rate between $98-100 \%$ within the diagnostic time, indicates susceptibility.

b) Mortality rate between $80-97 \%$ suggest possible resistance.

c) Mortality rate $<80 \%$ indicates resistance.

The percentage mortality was calculated by employing the formula as propounded by [19] as:

$\%$ Mortality $=\frac{\text { No. of dead larvae }}{\text { No.of larvae } \exp \text { osed }} \times \frac{100}{1}$

The Corrected percentage mortality was used when a proportion of the insects in the control batches died during the experiment. This was applied using Abbott's formula [20], represented as:

$$
P=\frac{\% P_{o}-\% P_{c}}{100-\% P_{c}} \chi \frac{100}{1}
$$

Where: $\mathrm{P}=$ Corrected Mortality

Po = Observed Mortality

Pc $=$ Control Mortality, all expressed in percentages

\section{Determination of $\mathrm{LC}_{50}$ and $\mathrm{LC}_{90}$}

Lethal concentrations $\left(\mathrm{LC}_{50}\right.$ and $\left.\mathrm{LC}_{90}\right)$ were determined by Probit analysis as described by Finney [21] for both samples at the different concentrations and times used in this study. The $\mathrm{LC}_{50}$ and $\mathrm{LC}_{90}$ are the lethal concentrations of the extract that kills $50 \%$ and $90 \%$, respectively of the larval population. It is important to note that the lower the $\mathrm{LC}_{50}$ and $\mathrm{LC}_{90}$, the more effective the larvicidal efficacy of the extract. Microsoft Excel regression probit analysis was employed. Percentage mortalities were converted to probits by looking up the percentage in Finney's table. The log of concentrations is calculated. A graph of probits versus the log of concentration is plotted to fit a line of regression. Extrapolating the probit of 5 in the $y$-axis to the $\mathrm{x}$-axis followed by taking the inverse of log of the extrapolated value on the $\mathrm{x}$-axis gives the $\mathrm{LC}_{50}$. A similar procedure was used to determine the $\mathrm{LC}_{90}$.

\section{Statistical Analysis}

Data obtained were analyzed using $\mathrm{R}$ Console software (Version 2.9.2). Mortality rate of the Anopheles larvae in relation to concentrations of extracts were compared using Pearson's Chisquare test. P-value $<0.05$ was considered statistically significant.

\section{Results and Discussion}

Results of qualitative and quantitative phytochemical screening of the leaves of M. aboensis showed that flavonoids was present in very high concentration from both extracts and leaf powder (Table 1). Flavonoids are hydroxylated phenolic substances synthesized by plants in response to microbial infection. They are also effective antioxidants, helping in the removal of oxidant free radicals $[22,23]$. They are health promoting compounds due to their active radicalscavenging potential [24].

Table 1: Results of Phytochemical Tests on Leaf Extracts and Leaf Powder of M. aboensis.

\begin{tabular}{|c|c|c|c|c|}
\hline$S / N$ & Phytochemicals & Aqueous Extract (\%) & Methanol Extract (\%) & Leaf Powder \\
\hline 1. & Saponins & $+++(14.45)$ & $+++(18.50)$ & ++ \\
\hline 2. & Flavanoids & $+++(19.80)$ & $+++(22.45)$ & +++ \\
\hline 3. & Tannins & $++(2.72)$ & $+++(6.20)$ & ++ \\
\hline 4. & Cardiac glycosides & $++(2.32)$ & $++(1.80)$ & ++ \\
\hline 5. & Resins & ++ & +++ & ++ \\
\hline 6. & Phenols & + & ++ & + \\
\hline 7. & Carbohydrates & ++ & ++ & ++ \\
\hline 8. & Steroids & + & ++ & + \\
\hline 9. & Terpenoids & + & ++ & + \\
\hline 10. & Alkaloids & $+(12.55)$ & $+++(39.75)$ & ++ \\
\hline 11. & Anthraquinones & - & - & - \\
\hline 12. & Phlobatannins & ++ & +++ & + \\
\hline
\end{tabular}

\section{Key}

$+++\quad=$

$++\quad=$

$+\quad=$

$=$
Present in very high concentration

Present in moderately high concentration

Present in low concentration

Not Detected 
Larvicidal Activity of Leaf Extracts and Powder of $\boldsymbol{M}$. aboensis against Anopheles gambiae larvae

Results of mortality rates recorded against An. gambiae by methanol, aqueous and leaf powder extract at varying concentrations (25-250 mg/ml) are presented in Table 2 .

\section{Exposure to Methanol Extract}

At 24 hours, $250 \mathrm{mg} / \mathrm{ml}$ concentration recorded highest mortality rate of An. gambiae larvae (70\%) followed by $125 \mathrm{mg} /$ $\mathrm{ml}$ and $75 \mathrm{mg} / \mathrm{ml}$ (68\%) then $50 \mathrm{mg} / \mathrm{ml}$ (67\%), $25 \mathrm{mg} / \mathrm{ml} \mathrm{(40 \% ),}$ while no mortality was recorded at $0 \mathrm{mg} / \mathrm{ml}$ (Table 2). There was a very high significant difference $\left(\chi^{2}=74.9297, \mathrm{df}=5, \mathrm{P}<0.0001\right)$ in mortality rate of An. gambiae larvae in relation to concentrations of methanolic extract of the leaf of $M$. aboensis. The larvae were resistant at 24 hours to the larvicidal activity of methanolic extract of the leaf of M. aboensis. At 48 hours, $250 \mathrm{mg} / \mathrm{ml}$ concentration had the highest mortality rate of An. gambiae larvae (99\%), 125 $\mathrm{mg} / \mathrm{ml}$ (98\%), $75 \mathrm{mg} / \mathrm{ml}$ (96\%), $50 \mathrm{mg} / \mathrm{ml}$ (90\%), $25 \mathrm{mg} / \mathrm{ml}$ (74\%), whereas no mortality was recorded at $0 \mathrm{mg} / \mathrm{ml}$ (Table 2). Hence, there was a very high significant difference $\left(\chi^{2}=97.0088\right.$, $\mathrm{df}=5, \mathrm{P}<0.0001$ ) in mortality rate of An. gambiae larvae in relation to concentrations. The larvae were susceptible at 125 $250 \mathrm{mg} / \mathrm{ml}$ concentrations but showed possible resistance at 50 $75 \mathrm{mg} / \mathrm{ml}$ concentration but were however resistant at $25 \mathrm{mg} / \mathrm{ml}$ concentration.

Table 2: Percentage Mortality of An. gambiae Larvae exposed to Extracts Millettia aboensis in relation to Time.

\begin{tabular}{|c|c|c|c|c|c|c|c|c|c|c|c|c|c|c|c|c|}
\hline M. aboensis & Time & \multicolumn{12}{|c|}{ \% Mortality Across Concentrations (mg/ml) } & \multirow[t]{3}{*}{$\chi^{2}$} & \multirow[t]{3}{*}{$\mathrm{df}$} & \multirow[t]{3}{*}{ P value } \\
\hline & & \multicolumn{6}{|c|}{ Observed } & \multicolumn{6}{|c|}{ Corrected } & & & \\
\hline & & 0 & 25 & 50 & 75 & 125 & 250 & 0 & 25 & 50 & 75 & 125 & 250 & & & \\
\hline \multirow{3}{*}{ Methanol } & 24 & 7.5 & 44 & 69 & 70 & 70 & 72 & 0 & 40 & 67 & 68 & 68 & 70 & 74.9297 & 5 & $<0.0001^{*}$ \\
\hline & 48 & 10 & 76.3 & 91.3 & 96.3 & 98 & 99 & 0 & 74 & 90 & 96 & 98 & 99 & 97.0088 & 5 & $<0.0001^{*}$ \\
\hline & 72 & 10 & 80 & 96 & 98 & 99 & 100 & 0 & 78 & 96 & 98 & 99 & 100 & 98.4904 & 5 & $<0.0001^{*}$ \\
\hline \multirow{3}{*}{ Aqueous } & 24 & 0 & 3 & 3 & 4 & 9 & 14 & - & - & - & - & - & - & 23.5455 & 5 & $=0.0002654^{*}$ \\
\hline & 48 & 0 & 19 & 13 & 8 & 14 & 36 & - & - & - & - & - & - & 49.0667 & 5 & $<0.0001^{*}$ \\
\hline & 72 & 0 & 25 & 14 & 10 & 16 & 41 & - & - & - & - & - & - & 55.7736 & 5 & $<0.0001^{*}$ \\
\hline \multirow{3}{*}{ Leaf Powder } & 24 & 0 & 20 & 31 & 35 & 38 & 75 & - & - & - & - & - & - & 92.1055 & 5 & $0.03058^{*}$ \\
\hline & 48 & 0 & 28 & 41 & 46 & 51 & 86 & - & - & - & - & - & - & 95.0952 & 5 & $0.001922 *$ \\
\hline & 72 & 0 & 49 & 56 & 70 & 73 & 95 & - & - & - & - & - & - & 90.6618 & 5 & $<0.0001^{*}$ \\
\hline
\end{tabular}

*: Significant

A. gambiae larvae were predominantly killed (100\%) by $250 \mathrm{mg} /$ $\mathrm{ml}$ concentration at 72 hours period followed by $125 \mathrm{mg} / \mathrm{ml}(99 \%)$ then $75 \mathrm{mg} / \mathrm{ml}$ (98\%), $50 \mathrm{mg} / \mathrm{ml}$ (96\%), $78 \mathrm{mg} / \mathrm{ml}$ (20\%), but no mortality was recorded at $0 \mathrm{mg} / \mathrm{ml}$ (Table 2). Therefore, there was a very high significant difference $\left(\chi^{2}=98.4904, \mathrm{df}=5, \mathrm{P}<0.0001\right)$ in mortality rate of An. gambiae larvae in relation to concentrations. The larvae were susceptible at $75-250 \mathrm{mg} / \mathrm{ml}$ concentration, and indicated possible resistance at $50 \mathrm{mg} / \mathrm{ml}$, but were resistant at 25 $\mathrm{mg} / \mathrm{ml}$ concentration. The results obtained showed progressive increase in percentage mortality as concentrations increased. The findings are in agreement with studies by Dakum [25] and Abok et al. [26] who investigated the larvicidal potency of the methanol leaf extract of $\mathrm{H}$. suaveolens against An. gambiae larvae, a possible reason being the similarity in the use of solvent for extraction, the same mosquito species tested, and the same Protocol applied for larvicidal testing. This agrees with the findings of Kholhring [27], who investigated the mosquitocidal activity of $M$. pachycarpa on the larvae and eggs of Ae. aegypti, recording peak mortality at the highest concentration of the extract, after total exposure time.
A possible reason for this may be the similarities in the use of plant species from the same family and similar solvents used for extraction.

\section{Exposure to Aqueous Extract}

At 24 hours exposure time, highest mortality rate of An. gambiae (14\%) was observed at $250 \mathrm{mg} / \mathrm{ml}$ concentration followed by 125 $\mathrm{mg} / \mathrm{ml}$ (9\%), $75 \mathrm{mg} / \mathrm{ml}$ (4\%), $50 \mathrm{mg} / \mathrm{ml}$ and $25 \mathrm{mg} / \mathrm{ml} \mathrm{(3 \% )} \mathrm{while}$ no mortality was recorded at $0 \mathrm{mg} / \mathrm{ml}$ (Table 2). Therefore, there was significant difference $\left(\chi^{2}=23.5455, \mathrm{df}=5, \mathrm{P}=0.0002654\right)$ in mortality rate of An. gambiae larvae in relation to concentrations of aqueous extract of the leaf of $M$. aboensis. The larvae were resistant at 24 hours exposure. The $250 \mathrm{mg} / \mathrm{ml}$ concentration had the highest mortality rate of An. gambiae larvae (36\%) at 48 hours followed by $25 \mathrm{mg} / \mathrm{ml}$ (19\%), $125 \mathrm{mg} / \mathrm{ml}(14 \%), 50 \mathrm{mg} / \mathrm{ml} \mathrm{(13 \% )} \mathrm{and} 75 \mathrm{mg} /$ $\mathrm{ml}(8 \%)$, whereas no mortality was recorded at $0 \mathrm{mg} / \mathrm{ml}$ (Table 2). Thus, there was a very high significant difference $\left(\chi^{2}=49.0667, \mathrm{df}\right.$ $=5, \mathrm{P}<0.0001$ ) in mortality rate of An. gambiae larvae in relation to concentrations. The larvae at 48 hours were resistant. The 
mortality rate of An. gambiae larvae was highest (41\%) at $250 \mathrm{mg} /$ $\mathrm{ml}$ concentration during the 72 hours exposure period followed by $25 \mathrm{mg} / \mathrm{ml}$ (25\%), $125 \mathrm{mg} / \mathrm{ml}$ (16\%), $50 \mathrm{mg} / \mathrm{ml} \mathrm{(14 \% )} \mathrm{and} 75 \mathrm{mg} /$ $\mathrm{ml}(10 \%)$, while no mortality was recorded at $0 \mathrm{mg} / \mathrm{ml}$ (Table 2). Hence, there was a very high significant difference $\left(\chi^{2}=55.7736, \mathrm{df}\right.$ $=5, \mathrm{P}<0.0001$ ) in mortality rate of An. gambiae larvae in relation to concentrations. The larvae were resistant at this hour.

After 24 hours of larval exposure to aqueous leaf extract, the result demonstrated very slow increase in percentage mortality as concentrations increased. At 48 hours exposure period, larval mortality showed an irregular pattern as mortality was high at 25 $\mathrm{mg} / \mathrm{ml}$ concentration, but started to decline steadily at $50-75 \mathrm{mg} /$ $\mathrm{ml}$. There was a sudden increase in mortality as concentration was increased to $125 \mathrm{mg} / \mathrm{ml}$ and peak mortality was recorded at 250 $\mathrm{mg} / \mathrm{ml}$. This gave an irregular pattern of larval mortality. After 72 hours exposure period, there was a similar irregular mortality rate pattern. Larval mortality was high at $25 \mathrm{mg} / \mathrm{ml}$ concentration, but started to decline steadily from $50-75 \mathrm{mg} / \mathrm{ml}$. There was a sudden increase in mortality as concentration was increased to $125 \mathrm{mg} /$ $\mathrm{ml}$ and peak mortality was recorded at $250 \mathrm{mg} / \mathrm{ml}$. This irregular pattern of larval mortality also gave an undulating mortality rate curve. A possible explanation for the irregular mortality rates recorded at the $24^{\text {th }}$ and 72 nd hour may be that the larvae developed some resistance to initial dose of the aqueous extract and were able to tolerate higher doses, but however lost their resistance when concentration was increased to the maximum. This result disagrees with the findings of Meenakshi and Jayaprakash [28] who investigated the mosquito larvicidal efficacy of leaf extract from mangrove plant Rhizophora mucronata against Anopheles and Aedes species and recorded $100 \%$ larval mortality at all concentrations after 48 hours exposure period.

Dakum et al. [25] and Abok et al. [26] who conducted similar experiments, recorded peak mortality at all concentration of the extract after 72 hours exposure time, which disagrees with the findings from the current experiment. The variations in results may be due to the conditions under which the experiments were conducted and the locations from which the larvae were collected and the variations in plant species used for extraction and larvicidal testing.

\section{Exposure to Leaf Powder}

At 24 hours, $250 \mathrm{mg} / \mathrm{ml}$ concentration recorded highest mortality rate of An. gambiae larvae (78\%), followed by $125 \mathrm{mg} / \mathrm{ml}$ (38\%), $75 \mathrm{mg} / \mathrm{ml}$ (35\%), $50 \mathrm{mg} / \mathrm{ml}$ (31\%), $25 \mathrm{mg} / \mathrm{ml}$ (20\%), while no mortality was recorded $0 \mathrm{mg} / \mathrm{ml}$ (Table 2). Therefore, there was a significant difference $\left(\chi^{2}=92.1055, \mathrm{df}=5, \mathrm{P}=0.03058\right)$ in mortality rate of An. gambiae larvae in relation to concentrations of the leaf powder of the leaf of $M$. aboensis. The larvae were resistant at 24 hours. At 48 hours, $250 \mathrm{mg} / \mathrm{ml}$ concentration recorded highest mortality rate of An. gambiae larvae (86\%), followed by $125 \mathrm{mg} / \mathrm{ml} \mathrm{(51 \% ),} 75 \mathrm{mg} / \mathrm{ml} \mathrm{(46 \% ),} 50 \mathrm{mg} / \mathrm{ml} \mathrm{(41 \% ),} 25 \mathrm{mg} / \mathrm{ml}$ (28\%), while no mortality was recorded at $0 \mathrm{mg} / \mathrm{ml}$ (Table 2). There was a significant difference ( $\left.\chi^{2}=95.0952, \mathrm{df}=5, \mathrm{P}=0.001922\right)$ in mortality rate of An. gambiae larvae in relation to concentrations. The larvae showed possible resistance at $250 \mathrm{mg} / \mathrm{ml}$ concentration but were susceptible however at $25-125 \mathrm{mg} / \mathrm{ml}$ concentrations. At 72 hours, $250 \mathrm{mg} / \mathrm{ml}$ concentration recorded highest mortality rate of An. gambiae larvae (95\%), followed $125 \mathrm{mg} / \mathrm{ml}$ (73\%), $75 \mathrm{mg} / \mathrm{ml}$ (70\%), $50 \mathrm{mg} / \mathrm{ml}$ (56\%), $25 \mathrm{mg} / \mathrm{ml}$ (49\%), while no mortality was recorded at $0 \mathrm{mg} / \mathrm{ml}$ (Table 2). There was a very high significant difference $\left(\chi^{2}=50.6667, \mathrm{df}=4, \mathrm{P}<0.0001\right)$ in mortality rate of An. gambiae larvae in relation to concentration. The larvae showed possible resistance at $250 \mathrm{mg} / \mathrm{ml}$ concentration but were however resistant at $25-125 \mathrm{mg} / \mathrm{ml}$ concentrations.

The results obtained demonstrated progressive increase in percentage mortality as concentrations increased. A possible reason for susceptibility recorded may be the fact that the leaf powder used up the dissolved oxygen available in the water, making it difficult for the mosquito species to survive. Chukwujekwu et al. [29]. who investigated the antiplasmodial diterpenoids from the leaves of $H$. suaveolens recorded similar finding. Also, Ombugadu et al. [30] recorded an increase in mortality of Anopheles larvae with increase in dosage of Capsicum chinensis.

\section{Comparison of the Efficacy of Three Treatments}

The larvae of An. gambiae showed progressive increase in mortality after 24 hours exposure period. The methanol leaf extract showed greater efficacy than the aqueous leaf extract and the leaf powder. However, at $250 \mathrm{mg} / \mathrm{ml}$, the leaf powder was more effective, recording the highest mortality than the methanol and aqueous leaf extracts. A possible explanation to this occurrence may be that larval mortality resulted from pollution of test habitat caused by the $250 \mathrm{mg} / \mathrm{ml}$ concentration of the leaf powder, which may have caused a decline in the amount of dissolved oxygen available for the juvenile larval population. This event may have promoted larval mortality at that concentration and time. This result disagrees with the findings of Dakum et al. [25]. who recorded recorded higher mortality rates of An. gambiae exposed to concentrations of the methanol leaf extract of $H$. suaveolens than those exposed to the aqueous leaf extract of the same plant. After 48-hour exposure period, larval mortality showed progressive increase at all concentrations. The methanol leaf extract proved to be more effective than the aqueous leaf extract and leaf powder, with peak mortality recorded at $99 \%$ of the methanol leaf extract at $250 \mathrm{mg} / \mathrm{ml}$. This is in agreement with the findings of Meenakshi and Jayaprakash [28], who also recorded higher mortality rates of An. gambiae and Ae. aegypti larvae exposed to the methanol leaf extract of Rhizophora mucronata. 
After 72 hours exposure period, larval mortality showed progressive increase at all concentrations. The methanol leaf extract proved to be more effective than the aqueous leaf extract and leaf powder.

\section{Lethal Concentration of Leaf Extracts and Powder of M. aboensis}

Table 3: $\mathrm{LC}_{50}$ for An. gambiae larvae Exposed to Leaf Extracts of Millettia aboensis.

\begin{tabular}{|c|c|c|c|}
\hline Time of Exposure (Hours) & \multicolumn{3}{|c|}{ Extract (mg/ml) } \\
\hline & Methanol & Aqueous & Leaf Powder (LD50) \\
\hline 24 & 25.12 & 3981.072 & 125.89 \\
\hline 48 & 8.91 & 7943.282 & 72.44 \\
\hline 72 & 5.13 & 6309.573 & 33.9 \\
\hline
\end{tabular}

Table 4: $\mathrm{LC}_{90}$ for An. gambiae larvae Exposed to Leaf Extracts of Millettia aboensis.

\begin{tabular}{|c|c|c|c|}
\hline Time of Exposure (Hours) & \multicolumn{3}{|c|}{ Extract (mg/ml) } \\
\hline & Methanol & Aqueous & Leaf Powder (LD90) \\
\hline 24 & 1995.262 & 109647.8 & 1071.519 \\
\hline 48 & 50.11872 & 3981072 & 501.1872 \\
\hline 72 & 33.88442 & 6918310 & 213.7962 \\
\hline
\end{tabular}

$\mathrm{LC}_{50}$ and $\mathrm{LC}_{90}$ values for Anopheles species in relation to leaf extracts and powder of $M$. aboensis are presented in Tables $3 \& 4$ respectively. Table 3 shows that the methanol leaf extract would be the most effective to use in order to yield $50 \%$ mortality rate at 24 , 48 and 72 hours against An. gambiae larvae. The leaf powder would be most effective in order to yield $90 \%$ mortality rate at 24 hours, while the methanol leaf extract would be most effective to kill $90 \%$ of Anopheles gambiae larvae at 48 and 72 hours Table 4.

\section{Conclusion}

Results obtained established that the methanol and aqueous leaf extracts, and leaf powder of M. aboensis can be used as an alternative to synthetic insecticides in control of Anopheles gambiae larvae at high concentrations. It is recommended that the extracts could be merged with various Pest Management programs. Repercautions of extracts on non-target organisms should also be investigated before its recommendation for use in vector control programme and commercial production.

\section{References}

1. Das P, Amalraj D D (2007) Biological control of Malaria Vectors. Indian Journal of Medical Research 106: 174-197.

2. Ohimain E I, Angaye T C N, Bassey S E (2014) Comparative Larvicidal Activities of the leaves, bark, stem and root of Jatropha curcas (Euphorbiaceae) against Malaria Vector Anopheles gambiae. Sky Journal of Biochemistry Research 3(3): 029-032.

3. Roll Back Malaria (2011) Malaria Key Facts (Accessed May 25 $5^{\text {th }}$, 2011).

4. Wendy CV, Goddard J, Harrison B (2012) Identification Guide to Adult Mosquitoes in Mississippi.

5. Radhika D, Ramathilaga A, Sathesh PC, Murugesan AG (2011) Evaluation of larvicidal activity of soil microbial isolates (Bacillus and Acinetobactor sp.) against Aedes aegypti (Diptera: Culicidae) - the vector of Chikungunya and Dengue. Proceedings of the International Academy of Ecology and Environmental Sciences, 1(3-4): 169-178.
6. Kumar MS, Maneemegalai S (2008) Evaluation of larvicidal effect of Lantana camara Linn against mosquito species Aedes aegypti and Culex quinquefasciatus. Biological Research 2: 39-43.

7. Corbel V, Ducon S, Zainm M, Hougand JM (2004) Dinotefuran: a Potential Neonicotinoid Insecticide against resistant Mosquitoes. Journal of Medical Entomology 41(4): 712-717.

8. Borase HP, Patil CD, Salunkhe RB, Narkhede CP, Salunke BK, et al. (2013) Phyto-synthesized silver nanoparticles: a potent mosquito biolarvicidal agent. Journal of Nanomedicine and Biotherapeutic Discovery 3: 111.

9. Mittal PK (2003) Biolarvicides in Vector Control: Challenges and Prospects. Journal of Vector Borne Diseases 40(1-2): 20-32.

10. Potters MF, Beavers GM (2005) Public Health Pest Management: A Training Guide, University of Kentucky, College of Agriculture p. 35.

11. Venketachalam MR, Jebasan A (2010) Larvicidal activity of Hydrocotyl javanica Thumb (Apjaceal) extract against Culex quinquefaciatus. Journal of Experimental Zoology India 4(1): 99-101.

12. Neuwinger H D (2000) African Traditional Medicine. A Dictionary of plant use and Applications. 1st Edition medpharm scientific publishers, Stuttgart pp. 978.

13. Lock JM (1989) Legumes of Africa: A checklist. $1^{\text {st }}$ edition Royal Botanical Garden, Kew.

14. National Bureau of Statistics (2006) 2006 Population Census, Federal Republic of Nigeria. Archived from the original on 2009-03-25.

15. Handa S S, Khanuja SPS, Longo G, Rakesh DD (2008) Extraction Technologies for Medicinal and Aromatic Plants, (1stedn), no. 66. Italy: United Nations Industrial Development Organization and the International Centre for Science and High Technology.

16. Vishnoi NR (1979) Advanced Practical Chemistry. Ghaziabad-India: Yikas Publication House, PVT Ltd 447-449.

17. Sofowora A (1993) Medicinal plants and Traditional medicine in Africa. Spectrum Books Ltd, Ibadan, Nigeria 289.

18. Trease GE, Evans W C (1989) Pharmacognosy. $13^{\text {th }}$ (edn.). ELBS/ Bailliere Tindall, London, 345-346: 535-536: 772-773.

19. World Health Organization (2013). Susceptibility Test Manual: Instructions for Determining the Susceptibility or Resistance of Mosquito Larvae to Insecticides. WHO/VBC/75.583. 
20. Abbott W B (1925) A method for computing the effectiveness of an Insecticide. Journal of Economic Entomology 18(2): 265-267.

21. Finney D J (1971) Probit Analysis, 3rd ed. Cambridge University Press, Cambridge 333. 60(9): 1432-1432.

22. Salah N, Miller NJ, Panange G, Tijburg L, Bolwell GP, et al. (1995) Polyphenolic flavonoids as scavenger of aqueous phase radicals as chai breaking antioxidant. Archives Biochemistry and Biophysics 322(2): 339-346.

23. Cai Y, Luo Q Sun M, Corke H (2004) Antioxidant activity and phenolic compounds of 112 traditional Chinese medicinal plants associated with anticancer. Life Science 74(17): 2157-2184.

24. Hausteen B (1983) Flavonoids, a class of natural products of high pharmacological potency. Biochemical Pharmacology 32(7): 1141-1148.

25. Dakum YD, Amajoh CN, Ombugadu A, Istifanus G, Agwom F, et al. (2021) Larvicidal Efficacy and GC-MS Analysis of Hyptis suaveolens Leaf Extracts against Anopheles species. International Journal of Biochemistry Research \& Review 30(1): 8-19.

ISSN: 2574-1241

DOI: $10.26717 /$ BJSTR.2021.39.006263

Pam VA. Biomed J Sci \& Tech Res

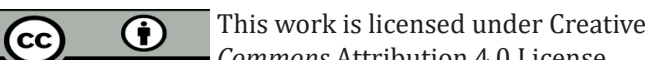

Submission Link: https://biomedres.us/submit-manuscript.php
26. Abok JI, Ombugadu A, Angbalaga GA (2018) Hyptis suaveolens Extract Exhibits Larvicidal Activity Against Anopheles gambiae Larvae. Tropical Journal of Natural Product Research 2(5): 245-249.

27. Kholhring L (2011) Mosquitocidal activity of Millettia pachycarpa on the larvae and eggs of Aedes aegypti. Scholars Research Library. Annals of Biological Research 2(3): 217-222.

28. Meenakshi SV, Jayaprakash K (2014) Mosquito larvicidal efficacy of leaf extract from mangrove plant Rhizophora mucronata (Family: Rhizophoraceae) against Anopheles and Aedes species. Journal of Pharmacognosy and Phytochemistry 3(1): 78-83.

29. Chukwujekwu JC, Smith P, Combes PH, Mulholland DA, Vanstanden J, et al. (2005) Anti plasmodial diterpenoids from the leaves of Hyptis suaveolens. Journal of Ethno pharmacology 102(2): 295-297.

30. Ombugadu A, Micah E M, Adejoh VA, Odey SA, Njila HL, et al. (2020) Capsicum chinensis (Hot Pepper) Powder Larvicidal Activity Against Mosquitoes Larvae in Lafia Local Government Area, Nasarawa State, Nigeria. Biomed Journal of Science \& Technology Res 31(5)-2020. BJSTR. MS.ID.005162.

$\begin{array}{ll}\text { BIOMEDICAL } & \text { Assets of Publishing with us } \\ \text { RESEARCHES } & \text { - Global archiving of articles } \\ \text { - Immediate, unrestricted online access }\end{array}$

